4 nordon 



\section{Rettighedsbaseret fiskeri til samfundets gavn}




\section{Rettighedsbaseret fiskeri til samfundets gavn}

TemaNord 2010:589

(C) Nordisk Ministerråd, København 2010

ISBN 978-92-893-2154-9

Tryk: Kailow Express ApS

Oplag: 130

Trykt på miljøvenligt papir som opfylder kravene i den nordiske miljøsvanemærkeordning.

Publikationen kan bestilles på www.norden.org/order. Flere publikationer på

www.norden.org/publikationer

Denne rapport er udgivet med finansiel støtte fra Nordisk Ministerråd. Indholdet i rapporten afspejler dog ikke nødvendigvis Nordisk Ministerråds synspunkter, meninger, holdninger eller anbefalinger.

Printed in Denmark

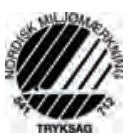

Nordisk Ministerråd

Ved Stranden 18

1061 København K

Telefon (+45) 33960200

Fax (+45) 33960202

\section{Nordisk Råd}

Ved Stranden 18

1061 København K

Telefon (+45) 33960400

Fax (+45) 33111870

\section{Det nordiske samarbejde}

Det nordiske samarbejde er en af verdens mest omfattende regionale samarbejdsformer. Samarbejdet omfatter Danmark, Finland, Island, Norge og Sverige, samt de selvstyrende områder Færøerne, Grønland og Åland.

Det nordiske samarbejde er både politisk, økonomisk og kulturelt forankret, og er en vigtig medspiller i det europæiske og internationale samarbejde. Det nordiske fællesskab arbejder for et stærkt Norden i et stærkt Europa.

Det nordiske samarbejde ønsker at styrke nordiske og regionale interesser og værdier i en global omverden. Fælles værdier landene imellem er med til at styrke Nordens position som en af verdens mest innovative og konkurrencedygtige regioner. 


\section{Indhold}

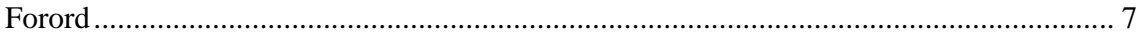

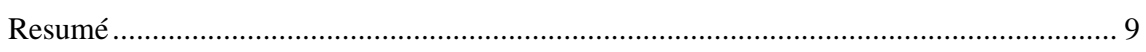

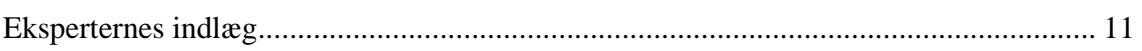

2.1 Gunnar Haraldsson, Senior Økonom, Fiskeridivisionen, OECD.......................... 11

2.2 Pórólfur Geir Matthíasson, professor i økonomi, Islands Universitet..................... 12

2.3 Jahn Petter Johnsen, Norges fiskerihøgskole ved Universitetet i Tromsø ............. 13

2.4 Óli Samró, fiskerikonsulent, Farec ....................................................................... 15

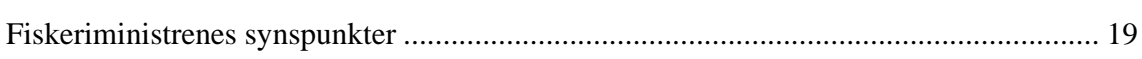

3.1 Jón Bjarnason, fiskeriminister, Island ............................................................... 19

3.2 Ane Hansen, fiskeriminister, Grønland ....................................................... 20

3.3 Jacob Vestergaard, fiskeriminister, Færøerne................................................... 21

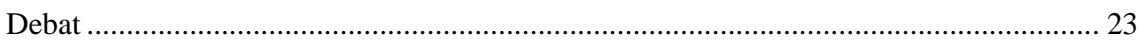

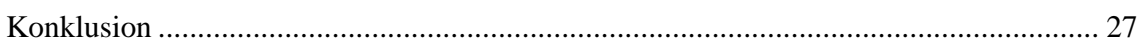





\section{Forord}

„Hvordan kan en rettighedsbaseret fiskeriforvaltning udnyttes til gavn for hele samfundet?“ var det overordnede spørgsmål på et seminar, som blev afholdt i Tórshavn på Færøerne 10. juni 2010. Seminaret var organiseret af Nordisk Ministerråd i samarbejde med Vestnordisk Råd og er en aktivitet i det færøske formandskab for Nordisk Ministerråds fiskerisamarbejde i 2010.

Med udgangspunkt i, at rettighederne til fiskeriressourcerne efterhånden er begrænset til nogle få udvalgte aktører, diskuterede forskere og politikere, hvordan det rettighedsbaserede fiskeri kan bidrage til velfærden i de vestnordiske fiskeriafhængige samfund.

Seminaret var en fortsættelse af Vestnordisk Råds Temakonference om de vestnordiske landes forskellige fiskeriforvaltningssystemer, som blev afholdt i Sauðarkróki i Island 8.-9.juni.

Seminarets formål var at belyse og diskutere forskellige former for allokering af fiskerirettigheder til aktørerne, hvor hensynet til samfundets andel af ressourcerenten sættes i fokus.

Denne rapport er en opsummering af indlæg fra forskere, fiskeriministrenes kommentarer og åben debat. Rapporten indeholder ikke anbefalinger til de politiske myndigheder om hvilke modeller med rettighedsbaseret fiskeri (Right Based Management, RBM) er de bedste og heller ikke hvordan ressourcerenten bedst kommer samfundet til gavn, men belyser fordele, ulemper og erfaringer med systemerne.

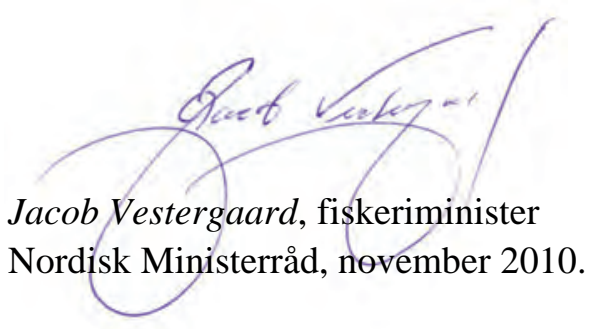





\section{Resumé}

Rettighedsbaseret fiskeri blev udredt og drøftet som begreb og metode for forvaltningspraksis. Rettighedsbaseret fiskeri blev derefter drøftet i perspektivet, at det skal være gavnligt for samfundet som helhed.

Titlen på seminaret indikerer at det er underforstået at fiskeriforvaltningen i Vestnorden i fremtiden vil blive baseret på en eller anden form for „rettighedsbaseret fiskeri“. Erkendelsen af, at adgang til fiskeriressourcerne er begrænset til nogle udvalgte, lå som en præmis for seminarets tema.

Som en konsekvens af at lukke det fri fiskeri, bygges en offentlig forvaltning op af fiskeressourcerne, som nødvendigvis baseres på, at der er nogle, som får rettigheder til ressourcerne og at andre ikke får disse rettigheder. Der indføres således en eksklusivitet i forvaltningen af ressourcerne, som har vist sig at generere store økonomiske værdier, som i praksis er knyttet til fiskerirettighederne - og skibene.

Rettighedsbaseret fiskeri har vist sig at have to meget store fordele. Den ene er, at systemet virker som et udmærket instrument i forbindelse med at tilpasse flådekapacitet til ressourcerne og den anden fordel er, at det er med til at fremme økonomien i fiskerierne.

Bagsiden af medaljen er derimod, at systemet har givet dem som er gået ud af fiskerierne store fordele, fordi de har solgt rettighederne for store summer, mens de nyankomne i fiskerierne sidder med tilsvarende stor gæld. For enkelte potentielle nyankomne kan den kalkulerede gældsbyrde være så stor, at de beslutter at fravælge fiskeriet som deres erhvervsmulighed og dermed kan systemet i enkelte tilfælde være en hindring for rekruttering. Der er også tvivl om hvorvidt den genererede ressourcerente kommer hele samfundet til gode.

Det grundlæggende spørgsmål og diskussionerne på seminaret handlede således om hvilke forventninger befolkningen kan have til at rettighedsbaseret fiskeri kan yde et økonomisk bidrag til samfundet, ud fra devisen om, at ressourcerne er folkets ejendom.

Dagen var delt i to sessioner. På formiddagen udredte fire eksperter væsentlige elementer i temaet. Gunnar Haraldsson fra OECDs Fisheries Policies Division, gav en generel indføring i modeller og erfaringer med det rettighedsbaserede fiskeri. Dórólfur Geir Matthíasson, professor i økonomi ved Islands Universitet, tog også udgangspunkt i de rettighedsbaserede fiskerier og hvordan man kan generere en ressourcerente heraf.

Jahn Petter Johnsen, førsteamanuensis i fiskeriforvaltning og fiskeriorganisering ved Universitetet i Tromsø, talte om de sociale, regionale og andre politiske drivkræfter, der påvirker udviklingen af fiskeriforvaltningerne generelt, og hvordan disse har indflydelse på udviklingen af det 
rettighedsbaserede fiskerisystem specielt. Og sidst kom Óli Samró, fiskerikonsulent fra Farec på Færøerne, med sit synspunkt på gældsudviklingen i de vestnordiske fiskerier.

I den efterfølgende paneldebat fremlagde fiskeriministrene i Island, Grønland og Færøerne deres synspunkter. Desuden kom en del spørgsmål og forslag angående rettighedsbaseret fiskeri fra økonomer, samfundsforskere og parlamentarikere. 


\section{Eksperternes indlæg}

De fire eksperter blev bedt om at have in mente i deres indlæg, at eftermiddagens session skulle være en politisk debat om visioner og politiske synspunkter om den fremtidige udvikling af fiskeriforvaltningen i Vestnorden. Inkluderet i disse forbehold var de nye politiske signaler fra Island om at inddrage fiskerilicenserne over en 20-årig periode og den færøske inddragning af alle licenser i 2018.

\subsection{Gunnar Haraldsson, Senior økonom, Fiskeridivisionen, OECD}

Gunnar Haraldssons indlæg var en generel indføring i modeller og erfaringer med rettighedsbaseret fiskeri. Hovedtemaet var, at der findes flere modeller, som myndighederne kan bruge til at gennemføre et rettighedsbaseret fiskeri. Forskellige modeller diskuteredes samt deres karakteristika og deres specielle egenskaber. Studier om forskellige systemer og erfaringer i OECD landene blev belyst og deres fordele og ulemper blev diskuteret. Focus var på relevansen for de vestnordiske lande.

OECD har i mange år studeret forskellige fiskeriforvaltningsmodeller og hvordan forvaltningen og resultaterne i fiskeriet kan forbedres. I de sidste 15 år er der i landene lagt mere vægt på rettighedsbaserede systemer. Ikke fordi disse systemer er uden problemer, men snarere fordi næsten alle systemer ikke har fungeret i den grad - eller på den måde - som forvaltningen havde håbet på.

Erfaringen med rettighedsbaserede systemer viser, at de er effektive til at frembringe økonomisk fordele både med hensyn til industrien, dvs. øget effektivitet i bedriften af virksomheden, men også med hensyn til ressourcen. Vel udførte rettighedsbaserede systemer gør, at fiskerne har incitamenter til at benytte ressourcen på en bæredygtig måde.

Haraldsson fremlagde en kortlægning af hvilke systemer og hvilke modeller forvaltningen/myndighederne kan bruge for at gennemføre et rettighedsbaseret fiskeri. ${ }^{1}$

Rettighedsbaserede systemer findes i mange forskellige udgaver, som passer til forskellige fiskerier. Vestnordiske fiskerier er teknisk avancerede og markeds-orienterede, hvor største delen af fangsten sælges på internationale markeder. Vestnordiske fiskerier har også en stor social og politisk vægt. Man må tage hensyn til disse faktorer, når systemerne skal udvikles

\footnotetext{
${ }^{1}$ OECD (2006). Using Market Mechanisms to Manage Fisheries. Smoothing the Path.
} 
Haraldsson fremførte, at TAC og fælleskvoter alene betyder, at fiskere kæmper imod hinanden. Anvendelsen af individuelle kvoter er en effektiv måde til at kontrollere fiskeriets indsats - effort - og til at øge økonomisk afkast og til at reducere, hvor mange aktører skal være i fiskeriet.

Ifølge Haraldsson viser erfaringen, at der hovedsagelig er to vigtige spørgsmål, som kommer op i forbindelse med design af systemet. Det første spørgsmål vedrører den oprindelige distribution af rettighederne, dvs. hvem skal få rettigheder og hvem ikke skal få rettigheder til at fiske. Det andet spørgsmål handler om hvad man skal gøre med den eventuelle rente som det nye system kan producere. Hvem skal have den - virksomhederne, statskassen, regionerne eller andre?

Disse spørgsmål er ikke kun politiske, men spiller en rolle i et vellykket fiskeriforvaltningssystem. Fiskeriforvaltningssystemer holder ikke i længden uden politisk støtte, sagde han, samtidig som han konkluderede, at rettighedsbaserede systemer desværre næsten altid bliver indført som følge af krise i erhvervet eller samfundet som helhed.

\subsection{Dórólfur Geir Matthíasson, Professor i økonomi, Islands Universitet}

Dórólfur Geir Matthíasson præsenterede i sit indlæg forskellige måder at vurdere værdien af ressourcerenten i Islands fiskeriindustri. Man kan fastsætte priser på kvoter, lejepris af kvoter eller udbytte af fiskeindustriens driftsresultater. Priserne er meget forskellige alt efter hvilke løsninger bliver valgt. Industriens driftsregnskab for årene 2007 og 2008 samt egne beregninger tyder på, at ressourcerenten i Island ligger omkring 22 milliarder ISK. Kvoteprisberegninger tyder på en rente, som ligger mellem 30 og 50 milliarder ISK. En del av forskellen kan forklares ved potentiel rentevækst som følge af bedre forvaltning af fiskebestandene.

Arbejdsproduktiviteten i islandske fiskerier tiltog betragtelig, da fiskerigrænsen blev udvidet til 200 sømil. Arbejdsproduktiviteten tiltog ligeledes, da kvotesystemet blev indført i 1980'erne. Man kan også registrere målt vækst i arbejdsproduktiviteten omkring 2005. Dette sidste kan dog være en form for kreativ bogføring. Vi kan i hvert fald ikke henvise til offentlige indgreb eller ændringer i rammebetingelser, som forklarer denne vækst.

Kvotesystemet i Island har dannet ressourcerente ved at reducere omkostningerne i selve fangstleddet. Fangsten er ikke blevet større og fiskebestandene har ikke vokset - med enkelte undtagelser. Dette tyder på, at den vurdering, som er blevet præsenteret på potentiel ressourcerente ved hjælp av driftsregnskab, burde danne en lavere grænse, idet det endnu er potentiale for at opbygge bestande og øge den årlige fangst.

Matthíasson fastslog, at ressourcerente i fiskerierne dannes ved at almenheden - via staten - øver vold mod potentielle aktører i fiskeriet og dermed begrænser rettigheden til at fiske til en nærmere defineret gruppe 
av individer og selskaber. Han fastslog også, at staten kan give rettigheden til individer eller selskaber uden vederlag, eller at rettigheden kan auktioneres eller lejes ud. I det første tilfælde tilfalder hele ressourcerenten til nogle få udvalgte. I det andet tilfælde kan ressourcerenten helt eller delvis overføres til almenheden. Dette aspekt har allerede været genstand til udtalelse fra FN's menneskerettighedskommission.

Til slut diskuterede Matthíasson „gavekvotesystemets“² konsekvenser for fiskeriselskabernes kapitalstruktur. Han henviste til, at fiskeriselskaber, som modtager „gavekvoter“ (dvs får tildelt kvota gratis), får udvidet sin egenkapital betragtelig og vil på forholdsvis kort tid begynde at operere som hedge-fonde ${ }^{3}$ med alle de konsekvenser, som det har for deres drift. Disse firmaer vil blive meget afhængige af international renteudvikling, af kredittilgængelighed på internationale kreditmarkeder og vil have store dele av sine indtægter - og eventuelle tab - fra finanssektoren og ikke fra fiskerierhvervet. Dette kan have dramatiske følger for lokale samfund, som er afhængige af den fiskerirelaterede aktivitet, som disse selskaber driver.

\subsection{Jahn Petter Johnsen, Første amanuensis, Norges fiskerihøgskole, Universitetet i Tromsø}

I sit foredrag satte Jahn Petter Johnsen spørgsmålet, hvilke sociale, regionale og andre politiske drivkræfter influerer på udviklingen af fiskeriforvaltningerne generelt og hvordan påvirker disse udviklingen af RBMsystemerne specielt. Historisk har udviklingen av RBM i det norske kystfiskeri en lang historie.

Norsk fiskeriindustri har siden 1930-årene været en vigtig del af norsk regionalpolitik. Organiseringen af norsk fiskeriindustri er følgende vokset frem i et tæt samspil mellem industri og myndigheder. Den organisatoriske transformation som skete i norsk fiskeriindustri i 1930årene havde sit udgangspunkt $\mathrm{i}$, at norsk fiskeriindustri var en bygdeindustri, som hovedsagelig var organiseret ud fra samarbejdsrelationer inden for husholdning og lokalsamfund. Dermed blev også det juridiske og institutionelle rammeværk, som blev udarbejdet for fiskeriindustrien, indrettet mod at industrien skulle organiseres i en korporativ samvirkemodel, som byggede på de lokale samarbejdsrelationer.

Den korporative model tog udgangspunkt $i$, at selvstændige og selvejende aktive fiskere gennem organiseret, og til dels lovbeskyttet samarbejde, skulle udvikle fiskeriindustrien til fiskernes, fiskerisamfundenes og storsamfundets bedste. Et av resultaterne var, at f. eks. fiskeri

\footnotetext{
${ }^{2}$ gavekvota $=$ grandfathering i engelsk sproget litteratur. Betegnelse for førstegangsallokering af fiskeriretigheder uden at skulle betale for disse.

3 “Hedge-fund" er en investeringsfond, som prøver at reducere variabiliteten i avkastning ved at investere i ukonvensionelle investeringsobjekter, som derivater, købe lån som andre lånere vurderer som for usikre.
} 
med trawl forudsatte specielle krav om tilladelse, ikke af hensyn til ressourcerne, men for at begrænse ejerskabskoncentration og kapitalistisk indflydelse i fiskeriindustrien. Frem til omkring 1990 havde fiskerne denne centrale rolle, en rolle som i en næsten planøkonomisk model hovedsagelig blev vedligeholdt gennem samarbejde med myndighederne og subsidier fra staten. Det gjorde det mulig at opretholde et system baseret på åben adgang og allemandsret i fiskerierne.

Sammenbruddet i den atlantoskandiske sildestamme i slutningen av 1960-årene var imidlertid begyndelsen til et gradvis paradigmeskifte i norsk fiskeriforvaltning. I 1973 førte dette til indføring af en koncessionsordning i sildesektoren. I kombination med kondemneringsordninger og muligheder for at købe fartøjer med kvoter - betinget omsættelighed førte paradigmeskifet til en stærk regional koncentration af rettigheder inden pelagisk sektor. Udover i 1980-årene blev det åbenbart, at subsidiepolitikken også førte til en overkapacitet i torskefiskerierne, en overkapacitet, som måske bidrog til sammenbruddet i den nordøstarktiske torskebestand omkring 1990. Dette sammenbrud udfordrede det åbne regime i torskesektoren, samtidig som subsidiepolitikken mødte stærk kritik, og det blev erkendt, at kapaciteten måtte reduceres. Spørgsmålet var, hvordan dette skulle gøres og hvilke konsekvenser det ville få?

Paradigmeskiftet førte til skifte i fokus i fiskeripolitikken, fra fiskerne og fiskerisamfundene, som de vigtigste klienter for politikken, til fokus på ressourcerne. En ny fiskeripolitisk model, som vi kan kalde ressourceforvaltningsmodellen fik gennemslag. Bærekraftige fiskerier blev det vigtige begreb, og hovedudfordringen blev nu at sørge for at fangstkapaciteten var i samsvar med ressourcegrundlaget. I første omgang blev der indført en midlertidig fartøjskvoteordning med en forventning af en mere omfattende strukturpolitik, og i 1991-92 blev der udarbejdet forslag til en omfattende strukturpolitik.

I de oprindelige forslagene lagde det norske fiskeridepartement op til en markedsorienteret model baseret på omsættelige kvoter, som i stor grad var et brud med den tidligere planøkonomiske model, som fiskeriindustrien var styret efter. Dette mødte imidlertid stærk modstand, både i fiskeriindustrien, i forvaltningen og blandt kystbefolkningen generelt. Resultatet blev en kompromismodel, der af hensyn til bærekraftig ressourceforvaltning blev overordnet, men i praksis tilpasset det eksisterende institutionelle rammeværk. Dette førte til, at strukturpolitikken ikke alene kunne lægge vægt på biologisk og økonomisk rationalitet, men at der også måtte tages hensyn til andre samfundsmæssige mål, som var knyttet til bosættelse, arbejde og regional fordeling. Blandt andet var det ønskeligt, at en rettighedsmodel ikke førte til for stærk koncentration af rettigheder. Denne kompromismodel bygger på flere pilarer:

For det første bygger modellen på den såkaldte Trawlstigen, som fastsætter, hvor stor andel av den totale norske torskekvote som skal fordeles til de konsessionsregulerede trawlere. For det andet er den konventionelle 
flåde inddelt i to grupper, en åben gruppe bestående hovedsagelig af mindre fartøjer, som fisker på en gruppekvote, og en lukket gruppe med garanterede fartøjskvoter. Deltagelse i den lukkede gruppe gives på grundlag af årlig deltageradgang til ejer og fartøj, som siden giver grundlag for tildeling af kvote ud fra fartøjets længde. Deltageradgangene tildeles automatisk fra år til år, hvis bådejer opfylder kriterierne.

For det tredje: For at undgå at små og store fartøjer skal konkurrere, er lukkede grupper opdelt i forskellige længdegrupper, som ikke konkurrerer med hinanden. Dette kaldes Finnmarksmodellen. Hver gruppe er tildelt en bestemt andel av totalkvoten, og det er først hvis det mod enden av en sæson for hele gruppen ikke ser ud at lykkes med at fiske sin kvote, at den enten refordeles, sådan at de mest effektive fartøjer i gruppen får en større kvote, eller refordeles til andre grupper.

For det fjerde er det i Norge i praksis åbnet for strukturering gennem omsætning af fartøjer med kvoter fra lukket gruppe og for sammenlægning av kvoterettigheder, men med visse begrænsninger i form av kvoteloft, afkortning af kvote ved salg og regionale begrænsninger. I princippet er der begrænsninger på salg av fartøjer fra et fylke til et andet, Finnmark undtaget, hvor fiskere har anledning til at købe fartøjer fra hele landet.

Statistik fra at Fiskeri- og kystdepartementet i Norge viser at strukturpolitikken og reguleringerne i kystfiskeriet i Norge havde fastholdt en relativ stabilitet i ressourcefordelingen mellem regionerne, men at der var foregået en centralisering af fordelingen i de enkelte regioner. Jahn Petter Johnsen viste også til at det norske Fiskeri- og kystdepartementets evaluering av politikken viser at lønsomheden i kystfiskeriet er forbedret betragtelig som konsekvens af strukturpolitikken.

Kort opsummeret er dagens rettighedsbaserede system i kystfiskeriet i Norge et system, hvor rettighederne er betinget og givet på bestemte vilkår. Selv om også Norge i større grad end tidligere benytter sig af markedsløsninger i strukturpolitikken, så er markederne begrænset af institutionelle overføringer fra tidligere fiskeripolitik og fra hensyn til samfundsmæssige mål. Norge har derfor ikke bevæget sig fra en planøkonomisk styring til en markedsstyring, men til en planmæssig og korporativ styring ved hjælp af markedsmekanismer. Rettighederne er med andre ord i samfundets tjeneste. Dette er helt i tråd med den blandingsøkonomiske nordiske model.

\section{4 Óli Samró, Fiskerikonsulent, Farec}

Óli Samró havde fået tildelt at tale om gæld samt om juridiske og økonomiske udfordringer med hensyn til udenlandsk kapital.

Samró fremførte, at der er begrænsninger på udenlandsk kapital både i Island, Norge og på Færøerne. Samtidig kunne han udlede, at en gennemgang af regnskaber viser, at færøske skibe med udenlandske ejere ikke bliver drevet anderledes, end lignende skibe med færøske ejere. 
Han oplyste, at udenlandsk kapital især er inde i kapitalintensive projekter, som er forbundet med stor risiko, og rederne har svaret, at de ønsker, at nuværende restriktioner skal være gældende. Sammenlignet med reglerne på Færøerne, har Island og Norge som EØS-lande store begrænsninger på udenlandsk kapital. Derimod har Shetland sammen med Skotland som EU-områder betydelig færre restriktioner på udenlandsk kapital samtidig som de sætter store krav til aktiviteterne.

Samró slog fast, at nøgleordet i fiskerierhvervet er „political risk“. En professionel investor vil altid vurdere den politiske risiko. Investorerne vil vurdere, om det politiske regime og de signaler, som disse sender ud, passer ind i fremtidsplanerne. Det er her, at risiko kommer ind i billedet for en økonomisk investor og det er her, tryghed kommer ind i billedet for en sociokulturel investor. Han mente, at der er to slags investorer i fiskeriindustrien. De fleste investerer af sociokulturelle årsager. De er fiskere af natur. Det ligger i rygmarven og de ønsker at forblive fiskere. For dem er det at fiske og alt, som hører dertil, ensbetydende med livet. De ønsker stabile rammebetingelser, således at den kulturelle arv kan flyttes videre til de kommende generationer. Er skipperne små, har de generelt stor politisk sympati. De har jo mange stemmer. Men mange skibsejere udvikler sig til at blive store og køber skibe i 100-millioner klassen. Når skipperne bliver store, skifter de titel og bliver redere. I Norge har disse ikke så megen politisk sympati, men i Island er det omvendt.

De senere år er der kommet en ny gruppe investorer, vi kan kalde dem eksterne investorer. Samró sagde, at for disse er finansielle begreber og nøgletal det vigtigste. Men både for de sociokulturelle redere og de finansielle investorer er et dybt kendskab til det politiske system og miljø en forudsætning. Spørgsmålet er så, hvordan nogen kan investere i en industri, der ikke følger markedsreglerne? Jo, fastslog Samró, de satser på politisk velvilje. Og det er her, at det politiske miljø får magt.

For banksektoren er det vigtigste derimod at få pant i fangstrettighederne. Får de det, er det muligt at give en form for lån. Er svaret nej, så er det en anden form for finansiering, de vil tilbyde med f. eks. større krav til egenfinansiering. De kan også vælge at trække sig ud. Den Danske Bank trak sig ud av fiskeri i begyndelsen av 1990'erne. Inden for nogle uger trak de sig ud af både Royal Greenland og Faroe Seafood. De troede ikke på fiskeriet og hovederhvervet både i Grønland og på Færøerne måtte finde nye investeringskilder.

Udenlandske investorer har akkurat den samme opfattelse som bankerne. De vil også sikre sig, at de kontrollerer fiskerirettighederne. Derfor handler spørgsmålet om gæld og om udenlandsk kapital om fiskerilovgivning - om denne giver mulighed for pant i fangstrettigheder. Er svaret ja, er det sandsynligt, at gælden vokser og at udenlandske investorer bliver interesserede. Men der er også stor risiko for, at gælden vokser uhæmmet og uden at skibene bliver fornyet. Det er Island er klart eksempel på. Er svaret nej, så er finansieringssituationen en helt anden. Samró 
ville ikke sige, at det ene er bedre end det andet, han skildrede kun, hvordan det har været. Den reelle magtkamp mente han står mellem dem, som ønsker at bevare fiskerisamfundet, som det er, og dem, som støtter sig til de markedsøkonomiske grundregler, hvor kapitalen bestemmer.

I 2000 sammenlignede Samró konkurrenceevnen for skibe i Norge, Island og på Færøerne. Et af spørgsmålende var, hvor længe islandske rederiers gæld kunne fortsætte med at vokse i betragtning af, at nogle af de andre faktorer i regnskabet slog fejl. Analysen viste tydelig, at de islandske rederier ikke havde en jordisk chance for at afdrage på gælden.

For de færøske rederier var konklusionen også klar. Vi kunne ikke se, at der skulle komme nogen ny økonomisk krise i den færøske fiskerisektor. Gælden var jo saneret efter bankkrisen i begyndelsen av 1990'erne. Men Samró erkender, at han tog fejl. Fra omkring 2004 kom der islandske bankaktører på banen. De færøske banker fulgte med og Færøerne fik islandske tilstande. Fra ingen gæld at have fik de samme skibe en stor gældsbyrde. Der findes flere forklaringer. For det første var det en trend at belåne friværdier og investere dem i andre aktiver. Bankerne havde likviditet og belåningsvilje. For det andet blev reglerne ændret, således at finanssektoren fik reel ret at få pant i fangstrettighederne. Aktivitet var nu først og fremmest rettigheder og i mindre omfang skibet. Udviklingen på Færøerne de følgende år blev den samme som på Island sidst på 1990tallet. Gælden er vokset, således at rederierne står med en stor gæld, især bygget på reel pant i licenser. Den reelle magt flyttede i en periode over til finansfolk. Men skibene er ikke blevet skiftet ud i bundfisk-sektoren og lønsomheden i denne del av flåden er særdeles svag og giver ikke rettighed til den store gæld. På den anden side findes der andre dele af flåden, som fremdeles har en lille eller ingen gæld.

Konklusionen er, at fiskerierhvervet i Island og på Færøerne vil på langt sigt udvikle sig som business as usual, men om det bliver inden for relativ kort tid er vanskelig at spå om. 



\section{Fiskeriministrenes synspunkter}

De tre ministrene fra Island, Grønland og Færøerne blev i deres indlæg bedt om at fremlægge regeringernes visioner for den fremtidige fiskeripolitik, samt at komme med deres synspunkter om, hvad vi kan lære af hinandens erfaringer med fiskeriforvaltning.

\subsection{Jón Bjarnason, Fiskeriminister, Island:}

Islands fiskeriminister Jón Bjarnason henviste til den aktuelle diskussion i Island omkring en revision af fiskeriforvaltningssystemet. Baggrunden for revisionen er, at den nye regering ser systemet med frit omsættelige individuelle kvoter som mislykket. Han kom ikke med direkte hentydninger om det var forvaltningen eller selve lovgivningen som havde slået fejl. Men regeringens klare synspunkt er, at det var uheldigt, at kvoterettighederne var blevet koncentreret hos er fåtal kvotebaroner og at få rettigheder var tilbage i regioner og bygder, som egentlig var bygget op omkring fiskerierhvervet.

Derfor skal fiskeripolitikken revideres. Svaret på, hvordan dette skal gøres er meget begrænset i øjeblikket, fordi et udvalg i disse dage er i færd med at udforme et forslag til en ny fiskerilovgivning. Én mulighed er, at de eksisterende kvoter kan inddrages og genuddeles på en ny måde indenfor de næste 20 år. Jón Bjarnason synspunkt er, , at fiskeriressourcerne skal være i folkets eje. Der skal ikke være tvivl om denne ejendomsret, hvorfor der også diskuteres i Island at sætte denne ret ind i Islands grundlov.

Det faktum, at fiskerisystemet i Island var blevet koncentreret i nogle få, store selskaber, som siden havde investeret kapitalen i andet end fiskeri, havde skabt vrede blandt befolkningen. Arbejdsgruppen har derfor fået som kommissorium at klarlægge, hvordan man kan nå frem til en fælles national forståelse af fiskerierhvervet og hvordan en ny lovgivning skal regulere fiskeriet. Det er også vigtigt, at det ikke reelt er bankerne, der ejer kvoterne, men at ejerskabet til kvoterne bliver i samfundets ejerskab, sagde Jón Bjarnason.

Bjarnason oplyste, at revisionen af fiskeripolitikken skulle udformes i to faser. I første omgang er det nødvendig med en kortsigtet reform, så fiskeriet kan fortsætte. Siden er det nødvendig med en langsigtet reform, som skal revidere selve kvotesystemet.

„Reformen skal tage udgangspunkt i, hvordan man bedst kan udnytte ressourcerne i havet med et bæredygtigt fiskeri, hvordan man sikrer arbejdspladser, sikrer kystsamfundets eksistens og skaber social enighed 
om fiskeriforvaltningen. Fiskeriet skal være biologisk, økonomisk og socialt bæredygtigt“, sagde Jón Bjarnason.

Han erkendte dog, at den nye lov bliver ikke bedre end de mennesker, som udarbejder den. Og han mente, at det derfor er nødvendigt, at folk sammen bygger det samfund op, hvor de gerne vil bo.

„Det har sin egen værdi og det har sin egen vej i excel-arkene. Derfor bliver resultatet ikke nødvendigvis det samme, som det var i går“, sagde Bjarnason.

Uden at gå i detaljer, er målet dog ifølge Bjarnason klart. Meningen er, at et begrænset kystfiskeri med en bestemt mængde pr. dag kan foregå uden at bådene skal have licens eller tildelte kvoter. Desuden er visionen, at alt skal komme i land i Island, tvs. hoveder, rygge, rogn, lever etc.

På spørgsmålet om, hvordan Island har tænkt sig at det fremtidige fiskeri bliver til samfundets gavn, sagde Bjarnason, at fisk i havet er en ressource og folkets ejendom på samme måde, som vandet i undergrunden er samfundets og folkets ejendom. Han oplyste, at arbejdsgruppen eventuelt kommer med forslag til en auktionsmodel, hvor rederne kan byde på rettigheder eller kvoter.

Bjarnason sagde, at i Island har folk en fornemmelse af, at det er bankerne, som ejer og driver rederierne. Men han ville hellere have, at det i stedet er samfundet og menneskene, som ejer og driver rederierne med den hjælp fra bankerne, som er nødvendig, uden at blive helt afhængig af bankene.

\subsection{Ane Hansen, Fiskeriminister, Grønland:}

Ane Hansen redegjorde for, at samfundet skal have størst mulig økonomisk udbytte af fiskeriet, men at man først grundlæggende må have afklaret spørgsmålet om hvem der ejer ressourcerne. Hun mente, at de levende og fornybare ressourcer er samfundets fælleseje. Derfor må de personer eller selskaber, der har fået tildelt en eksklusiv udnyttelsesret også betale for at udnytte disse ressourcer, i det omfang denne aktivitet genererer et økonomisk udbytte.

„Fiskeressourcerne i havet er fælles eje og folkets ejendom, som bør give afkast til befolkningen, men akkurat hvordan man gør det er op til myndighederne sammen med befolkningen at enes om“, sagde Ane Hansen. Hun oplyste dog, at auktionsmodellen for kvoter, hvor ressourcerenten går direkte i statskassen, er blevet diskuteret i Grønland.

Et ejerskab til fiskekvoter bør heller ikke indgå i en ejers finansielle spekulationer. Hansen vurderede således, at et rettighedsbaseret kvotesystem kunne være en god mulighed for at sikre et bæredygtigt fiskerierhverv - både biologisk og økonomisk, så længe der fastholdes det grundlæggende princip, at kvoter er samfundets eje, som skal forvaltes med omtanke og hensyn til det øvrige samfund. 
Ane Hansen pointerede, at grønlandsk fiskeriforvaltning hidtil har haft gode erfaringer med individuelle kvoter i rejefiskeriet, siden systemet blev indført i 1990. På den tid var der alt for mange aktører og kvoterne for små. Desuden var der problemer med udkastning og kun de bedste rejer blev ført i land. Alligevel gik en række rederier konkurs.

„Efter at systemet med individuelle, omsættelige kvoter blev indført, førte dette til større og langt færre aktører i fiskeriet, som dermed blev mere lønsomt og bæredygtig. Derfor vil vi revidere systemet angående det kystnære fiskeri efter hellefisk“, sagde Ane Hansen.

En fiskerikommission har for nylig afleveret forslag til en ny fiskerilovgivning. Den skal ifølge Hansen bygge på principperne om TAC over flere år, ansatte i fiskeriet skal reduceres og omsættelige individuelle kvoter skal generelt indføres. Dette mener Hansen vil gøre fiskerierhvervet bæredygtigt og rentabelt med størst mulig afkastning. Derudover skal unge fiskere få lettere adgang end nu til fiskeriet. Kommissionen har endvidere påvist, at dette system har vist sig som det mest fleksible og fordelagtige system for Grønland.

Ane Hansen pointerede også, at det nye lovforslag for fiskeri vil individuelt omsættelige kvoter i Grønland vi have tilknyttet lovkravet om et tæt tilhørsforhold til Grønland, hvorfor det bliver sværere for udenlandske aktører at drage nytte af disse kvoter i Grønland. Desuden skal kvoterne tidsbegrænses.

Ane Hansen gav også udtryk for, at de vestnordiske lande i fremtiden ikke kunne undgå at arbejde sammen om fælles fiskeressourcer. „Derfor er det meget nødvendigt, at vi arbejder på et fælles system. Dette samarbejde burde også omfatte spørgsmål der relaterer til et videnskabeligt funderet samarbejde omkring fiskeriets økonomiske forhold, især da Grønland ikke selv har institutioner der danner grundlag for undersøgelser af det samlede fiskeris økonomiske aspekter og som udgør landets vigtigste erhverv“.

\subsection{Jacob Vestergaard, Fiskeriminister, Færøerne:}

„Samfundet skal få størst muligt udbytte af de rettighedsbaserede fiskerier. Som liberal politiker med tiltro til markedsbaseret erhverv, sætter jeg mig tvivlsom til at sælge kvoter og fiskedage på offentlig auktion. Vi må ikke dræbe hønen, som lægger guldæg. Og jeg mener ikke, at offentligt salg af rettigheder skaber grundlag for vækst på Færøerne eller i Vestnorden. De private finansielle midler til erhvervet skal bruges til at styrke erhvervets konkurrencedygtighed og fremtidige udfordringer. Jeg mener ikke, at en del af udbyttet fra fiskeriet skal overføres til statskassen“, var Jacob Vestergaards utvetydige udsagn om, hvilke overførelseskanaler af eventuel ressourcerente, han ikke kunne godtage. 
På hvilken anden måde samfundet kunne få størst mulig udbytte af de rettighedsbaserede ressourcer ville han ikke kommentere yderligere, fordi han havde samme begrænsning til at udtale sig, som den islandske fiskeriminister, eftersom et udvalg for tiden behandler en eventuel revidering af det færøske fiskedagesystem.

Vestergaard var enig med de andre om, at fisken i havet er folkets ejendom og at de politiske myndigheder forvalter denne ejendom. Det sensitive spørgsmål er derimod, hvordan man administrerer det, som samfundet ejer. Vestergaard var f.eks. ikke fortaler for regional opdeling af ressourcerne, men det beror mest på, at han mente, at Færøerne ikke har råd til det.

Vestergaard pegede ellers på, at der var delte meninger om hvor vellykket den færøske fiskeripolitik har været siden Færøerne i 1994 fik et nyt system med omsættelige individuelle kvoter, som i 1996 blev ændret til en fiskedageordning inden for 200 sømil. Selv mente han, at systemet havde fungeret godt for en del af fartøjsgrupperne, men spørgsmålet er, om nuværende opdeling av de forskellige fartøjsstørrelser er hensynsmæssig, bl.a. fordi der er sat nogle forbud mod at flytte rettigheder mellem disse fartøjsgrupper.

Jacob Vestergaard medgav, at disse forbud hindrer en optimal udnyttelse af fiskedage, hvorfor der nu påtænkes at lægge nogle mekanismer ind i systemet, som sikrer en fuld udnyttelse af rettighederne og skal sikre en optimal bevægelighed af rettighederne. Disse mekanismer står i relief til de mekanismer, som handler om at lovgive for at rederierne forpligter sig til at udnytte rettighederne, de har fået tildelt.

En mulighed for at opnå større bevægelighed i systemet, er at udvide systemet med omsættelige kvoter. Nuværende lovgivning giver hjemmel til en gennemgribende reform af forvaltningsystemet inden 2018., da det færøske parlament for et par år siden vedtog, at samtlige fiskerilicenser skal inddrages senest 1. januar 2018.

Både i det havgående fiskeri efter bundfisk inden for 200 sømil og i det internationale fiskeri på fælles bestande har man med tiden fået færre aktører, således at fiskeflåden har tilpasset sig ressourcerne med større udbytte for de tilbageværende aktører. Vestergaard mente, at systemet specielt har virket godt i f.eks. det pelagiske fiskeri. 


\section{Debat}

Efter fiskeriministrenes indlæg om de forskellige landes politik og forvaltning af fiskerilovgivningen, blev der åbnet for debat mellem alle seminardeltagere.

En del av debatten gav udtryk for, at både Island og Færøerne havde ønske om at pointere den oprindelige tanke om at fiskeriressourcerne er ejet af folket og at de skal forvaltes som fælleseje. Baggrunden for dette synspunkt var især den tvivlsomme udvikling af de individuelle omsættelige fiskerettigheder, først og fremmest i Island, men til dels også på Færøerne.

Gunnar Haraldsson fra OECD efterlyste en dybere forklaring på, hvorfor Island og til dels Færøerne ønsker at gå fra individuelle omsættelige kvoter tilbage til andre reguleringer. Haraldsson pointerede, at fiskerierhvervet er karakteriseret ved at være et gennemreguleret erhverv. Han medgav dog at til trods for dette, er fiskerierhvervet en af de sidste økonomiske aktiviteter, hvor rettighederne angående ressourcerne ikke er vel defineret. Haraldsson fremhævede derfor, at fiskeriforvaltning ikke handler om forvaltning af fisk, men om forvaltning af mennesker. Han var enig i, at det var i orden at revurdere fiskeripolitikken og at søge efter de rette instrumenter i forvaltningen, men han advarede imod at slagte hønen, der lægger guldæg, alene fordi man ikke kan blive enige om at fordele guldæggene! Dermed slog han fast, at fordelingsnøglen til kvoter udgør et vigtigt instrument til at regulere fiskeriområdet til gavn for samfundet.

pórólfur Geir Matthíasson, professor i økonomi ved Islands Universitet, filosoferede over det afgørende spørgsmål om, hvordan ressourcerenten kan komme samfundet til gavn. Hans synspunkt var, at uanset om renten ikke bliver taget ind gennem skatter, afgifter eller ved auktion, så kommer renten til gode på andre måder. Når det regner på præsten, drypper det på degnen. Når f.eks. en fiskebådreder køber en stor Toyota, så får salgspersonen lidt penge ud af det samtidig som samfundet får registreringsafgift. Det samme sker, når kvotehandlere involverer mæglere og advokater.

Andre metoder for at overføre renten til samfundet er f.eks. ved kvoteauktion. Denne metode er den mest brutale. Hvis auktionarius er en offentlig kvotebank, vil næsten hele renten tilfalde den offentlige sektor. Desuden kan kommuner leje kvoter til fiskeaktører i regionerne Og derved få indtægter af kvotaerne.

Ødelæggende mekanismers kraft, som berøver samfundet for ressourcerente, viser sig, når kvotabaroner giver bankerne pant i kvoterne og dermed får grønt lys for at gøre investeringer i andet end fiskerierhvervet. Udfaldet kan være, og har været, at selskaber går konkurs på grund af kapitalrekon- 
struering, til trods for at selve fiskeridriften går strålende. Resultatet er, at lokalsamfund forsvinder, fordi folk i California har problem med boliglån.

Haraldsson henviste til det faktum, at når man har ressourcerente, så slås man om den. Derfor var det obligatorisk spørgsmål, hvad renten skal bruges til og hvem den skal tilfalde. Han pointerede, at man i de fleste lande siger, at kvoterne ikke er en ejendom over fisken i havet, men det er en ejendom af rettighederne at fiske en bestemt procentdel av totalkvotaen. Det er ikke det samme. Selv om man er statsborger og har nogle licenser, har man ikke frihed til at gøre det som man vil.

Med baggrund i, hvor vitalt det er med overskud i fiskeriet, dersom samfundet kan få gavn af fiskerierhvervet, rejste den færøske økonom og parlamentariker, Magni Laksafoss, hård kritik mod det færøske fiskedagesystem. Han fremførte, at færøske politikere har givet udtryk for, at det færøske fiskedagesystem er et særdeles velfungerende system. Dette synspunkt kunne han absolut ikke dele. Han mente, at selve systemet eller forvaltningen af systemet var årsag til, at torskebestanden var nedfisket og at fiskeflåden de seneste 10 år har haft negativt afkast. Derfor konkluderede han, at systemet var hverken biologisk eller økonomisk bæredygtigt.

Fejlen i systemet er ifølge Laksafoss, at fiskedagene først og fremmest bliver vurderet i torskebestanden og at det i udgangspunktet er for let for fiskerne at gå ud at fange torsken, fordi den er det mest indbringende. Når man så skal vurdere, om fangsttrykket er for hårdt, tager man udgangspunkt i torskebestanden. Har torskebestanden det ikke godt, nedsætter man antallet af dage ud fra torskebestanden, også for de både og skibe, som ikke fanger torsk.

Laksafoss sagde, at hovedargumentet med et system må være at fiskerne skal tjene penge. Han gav udtryk for, at han ikke delte Vestergaards synspunkt om, at dersom du er liberal, skal du ikke tage ressourcerenten fra fiskerne. Har man et system som det færøske, som næsten kan sammenlignes med frit fiskeri, så har du stadigvæk en ressourcerente. Men renten bliver bare fordelt på, at en overkapacitet går ud og nedfisker bestanden.

Indfører man begrænsninger, således at ressourcerenten kommer ud i kroner og øre, så kan den blive fordelt på mange forskellige måder, sagde Laksafoss. Den kan f.eks. fordeles ud til bankerne, som fiskerierhvervet står i stor gæld til. Fiskerne kan også få en højere løn ved at uddele ressourcerenten til dem, uden at dette nødvendigvis medfører en højere profit til fiskeriselskaberne.

"Derfor er ressourcerenten der, uanset hvad, det er bare et spørgsmål om, hvem skal have den. Det primære må være at skabe et system, og derefter diskutere hvordan disse penge skal administreres: Om det er folkets ejendom, som skal kræves ind til den offentlige kasse eller om vi skal følge den borgerlige tankegang, som siger, at erhvervet selv skal beholde pengene, sådan at fiskeindustrien kan sætte pengene i andre erhverv og dermed være med til at skabe vækst i andre områder”, sagde Magni Laksafoss. 
I sit svar til denne kritik var fiskeriminister Jacob Vestergaard af den opfattelse, at det færøske fiskedagesystem ikke har spillet fallit, men systemet har nogle uheldige hindringer eller forbud, både med hensyn til hvordan man kan sælge fangsten og hvordan man kan flytte fiskedage mellem de forskellige fartøjsgrupper. Disse hindringer har gjort, at nogle fartøjsgrupper ikke kan optimere driften. Disse forhold vil blive nærmere undersøgt, således at vi får bedre udnyttelse med færre med stærkere aktører, sagde Vestergaard

Ud fra det politiske faktum, at den sociale komponent i bæredygtighed er opadgående og at det regionalpolitiske element dermed bliver stærkere, ville Ásmundur Guðjónsson, senior rådgiver, NMR, vide hvordan regionalpolitiske hensyn påvirker genereringen av ressourcerenten i fiskerierne

pórólfur Geir Matthíasson mente at dette kunne gøres på flere måder. Som udgangspunkt kan man ved at generere mest mulig ressourcerente indkassere pengene og bruge dem i de regioner, som man vil styrke. Man kan også fastsætte tildelingen af et bestemt antal kvoter til udvalgte regioner, som siden enten kan leje kvoterne elle tildele dem til de aktører, som formår at bruge dem optimalt. Matthíasson tilføjede dog, at bruger man denne fremgangsmåde, er det meget sandsynlig, at den totale rente bliver lavere, end hvis du enten har fri konkurrence om kvoterne eller du sælger dem på fri auktion. Udfordringen er, sagde Matthíasson, at have klare mål og siden at bruge det rettighedsbaserede system som instrument. Det endelige mål er ikke at have et bestemt type system, fordi det grundlæggende er, hvilke resultater du kan skabe.

Angående den sociale bæredygtighed tilføjede Gunnar Haraldsson, at tiderne kræver ændringer og at alt må ses i en helhed. Vi har jo også set forandringer i det islandske landbrug, som har medført, at folk er flyttet til Reykjavik. Han nævnte, at Norge har penge til social bæredygtighed, men spørgsmålet er, om Island og Færøerne har råd til det.

Jahn Petter Johnsen, førsteamanuensis i fiskeriforvaltning, mente ikke, at den norske model kunne overføres til andre lande, til trods for at de økonomiske love er de samme. Han pointerede, at Kystnorge blev ikke subsidieret med oljepenge, men indrømmede, at dersom Norge ikke havde oljen, ville der selvfølgelig være langt flere arbejdspladser i fiskerierhvervet, samtidig som levestandarden i fiskeriet ville være lavere.

Fiskeriminister Ane Hansen gav udtryk for, at de vestnordiske lande i fremtiden ikke kunne undgå at arbejde sammen om de fælles ressourcer. „Derfor er det meget nødvendigt, at vi arbejder på et fælles system. Dette samarbejde burde også omfatte spørgsmål der relaterer sig til et videnskabeligt funderet samarbejde omkring fiskeriets økonomiske forhold, især da Grønland ikke selv har institutioner der danner grundlag for undersøgelser af det samlede fiskeris økonomiske aspekter og som udgør landets vigtigste erhverv“.

Der var således enighed blandt seminarets deltagere om, at fiskeriressourcerne skal forvaltes til størst mulig gavn for samfundet. Josef Motz- 
feldt fremhævede i denne sammenhæng, at der på baggrund af temakonferencen i Island og seminaret på Færøerne nu kan fastslås, at de levende ressourcer i de vestnordiske lande der udgør fællesbestande også bør forvaltes i et fællesskab. 


\section{Konklusion}

Der var blandt seminardeltagerne bred enighed om, at et rettighedsbaseret fiskeri er en grundlæggende forudsætning for at opnå det maksimale økonomiske udbytte i forbindelse med udnyttelsen af fiskeressourcerne. Modsat et system med fri adgang til ressourcerne begrænser et rettighedsbaseret system de produktionsfaktorer, der anvendes i fiskeriet, til det, som er optimalt for at opnå et højt vedvarende udbytte. Med en hensigtsmæssig forvaltning er der med rettighedsbaseret fiskeri derfor udsigt til både biologisk, økonomisk og socialt bæredygtig erhverv.

Både i teori og praksis har man erfaret, at åben adgang til fiskeri ikke fører til et bæredygtigt fiskeri, eller til det maksimale økonomiske udbytte af fiskeriet. Frit fiskeri fører til en overkapitalisering og det økonomiske afkast af fiskebestandene forsvinder som følge af, at de enkelte fiskere i olympisk fiskeri søger at fange så meget som mulig. Teorien peger derimod på, at med et rettighedsbaseret fiskeri vil fiskebestandene stabiliseres på et højere niveau som giver størst økonomisk afkast. Ved en økonomisk optimal forvaltning af fiskerierne dannes ressourcerente, som er et udtryk for det ekstra afkast som stammer fra at kvotaerne allokeres gratis.

Stort set er der også en fælles forståelse for, at fiskerettighederne er samfundets fælles eje, som myndighederne forvalter. Og selv om der også er enighed om principperne for, hvordan fiskerierhvervet genererer størst mulig økonomisk afkast, er der ikke enighed om, hvordan ressourcerenten bør komme samfundet til gavn

Debatten var til dels præget af de uheldige erfaringer med at fiskerirettigheder er blevet kapitaliseret og indgået i selskabernes egenkapital, hvilket igen har dannet muligheder for selskaberne at stifte lån til store investeringer udenfor fiskerierhvervet.

Disse erfaringer er nødvendigvis ikke nogen bevis for, at modellen med individuelle omsættelige rettigheder (kvota eller fiskedage) er forkert og der blev derfor advaret imod at slagte hønen, der lægger guldæg.

Generering af ressourcerente blev også grundigt debatteret. Størrelsen af ressourcerenten kan vurderes og ligger for Islands vedkommende et sted mellem 30 og 50 milliarder ISK. Det politiske spørgsmål om hvem der skal have denne ressourcerente, genstår at blive besvaret. Spørgsmålet om hvordan ressourcerenten kan komme samfundet til gavn er et yderst politisk sensitivt spørgsmål. Dette var de tre fiskeriministre meget bevidste om og understregede, hvor vigtig det er, at lovgivningen og forvaltningen af fiskerirettigheder og ressourcerente har bred opbakningen i befolkningen, i fiskerierhvervet og i det politiske miljø.

Men tilbage står politikernes pligt at se til, at „samfundets ejendom“ giver et acceptabelt afkast og at dette afkast kommer samfundet til gode. 